\title{
LE CHANSONNIER FRANÇAIS U, publié d'après le manuscrit Paris, BNF, fr. 20050 par Madeleine TYSSENS
}

Walter Meliga

\section{OpenEdition}

Journals

Edizione digitale

URL: http://journals.openedition.org/studifrancesi/14917

DOI: 10.4000/studifrancesi. 14917

ISSN: 2421-5856

\section{Editore}

Rosenberg \& Sellier

\section{Edizione cartacea}

Data di pubblicazione: 1 décembre 2018

Paginazione: 474

ISSN: 0039-2944

\section{Notizia bibliografica digitale}

Walter Meliga, «LE CHANSonnier français u, publié d'après le manuscrit Paris, BNF, fr. 20050 par madeleine TYSSENS», Studi Francesi [Online], 186 (LXII | III) | 2018, online dal 01 janvier 2019, consultato il 06 janvier 2021. URL: http://journals.openedition.org/studifrancesi/14917 ; DOI: https://doi.org/10.4000/ studifrancesi. 14917

Questo documento è stato generato automaticamente il 6 janvier 2021.

\section{(c) (i) (9)}

Studi Francesi è distribuita con Licenza Creative Commons Attribuzione - Non commerciale - Non opere derivate 4.0 Internazionale. 


\title{
LE CHANSONNIER FRANÇAIS U, publié d'après le manuscrit Paris, BNF, fr. 20050 par Madeleine TYSSENS
}

\author{
Walter Meliga
}

\section{NOTIZIA}

LE CHANSONNIER FRANÇAIS U, publié d'après le manuscrit Paris, BNF, fr. 20050 par madeleine TYSSENS, Tome I, Paris, Société des Anciens Textes Français, 2015, 407 pp.

1 Si tratta dell'edizione dei primi 180 componimenti, ovvero della sezione più antica, del celeberrimo Chansonnier de Saint-Germain-des-Prés, che si collega in ideale prosecuzione all'altrettanto celebre riproduzione fototipica che nel 1892 ne avevano dato P. Meyer e G. Raynaud, sempre nella collana della SATF. All'edizione è premessa un'introduzione codicologica sulla storia e la composizione dell'antologia poetica nonché sull'organizzazione della tavola antica; inoltre è brevemente ma precisamente affrontato il problema della posizione di $U$ nella tradizione manoscritta della lirica d'oil, a partire dallo studio fondante di E. Schwan. L'edizione è critica, secondo le regole dell'edizione a testimone unico, ma con due importanti complementi: una notice introduttiva per ogni componimento, con informazioni su tradizione manoscritta, metrica e attribuzione e talora una breve discussione testuale, e soprattutto un apparato critico che ha lo scopo precipuo di «situer U dans l'ensemble de la tradition» (p. xL), con indubbi vantaggi per la cosiddetta «filologia dei canzonieri». In questo modo l'editrice riprende una prassi editoriale importante e gloriosa nella tradizione filologica, migliorandola e portandola a un ottimo risultato. 